\title{
ANAEROBIC BIODEGRADATION OF DDT IN CONTAMINATED SOIL BY BIOSTIMULATION: LABORATORY AND PILOT-SCALE STUDIES
}

\author{
MARÍA A. PRADA-VÁSQUEZ, SANTIAGO A. CARDONA-GALLO, \\ JUAN C. LOAIZA-USUGA*
}

Universidad Nacional de Colombia, Sede Medellin, Facultad de Minas, Departamento de Geociencias y Medioambiente, Colombia

*Coresponding author: jcloaiza@unal.edu.co

\begin{abstract}
Bioremediation of 1,1,1-trichloro-2,2-bis(4-chlorophenyl) ethane (DDT) by biostimulation of native microbial populations in soil was investigated in a lab-scale and pilot scale under anaerobic conditions. To evaluate the role of molasses (co-substrate) and potassium nitrate (electron acceptor) in the reductive dechlorination of DDT, experiments were conducted in a microcosm using five treatments: (T1) control, (T2) natural attenuation, (T3) molasses, (T4) molasses + potassium nitrate and (T5) potassium nitrate. Results showed that after 30 days of incubation, DDT concentration was reduced by $30.3 \%$ in the control, $32.85 \%$ for natural attenuation, $72.3 \%$ with addition of molasses, $92.5 \%$ for amendments with molasses + potassium nitrate, and $70.2 \%$ for biostimulation only with potassium nitrate. An upscaling of the microcosm to a larger fixed-bed reactor was conducted for treatment T4. After one month of incubation, DDT concentrations in the reactor decreased by $91.54 \%$ of the initial quantities. The DDT biodegradation rate fit a pseudo-first-order kinetic decay function and declined to $0.077 \mathrm{~d}^{-1}$, with half-life of 8.9 days in the absence of oxygen. Predominant microbial strains were isolated and identified through biochemical and molecular tests before and after the bioremediation process. The microorganisms isolated were identified as Bacillus circulans and Bacillus megaterium before and after the treatment application, respectively. This study provides evidence that the combination of a donor electron substance (molasses) and acceptor electron $\left(\mathrm{KNO}_{3}\right)$ can enhance the DDT biodegradation rates under anaerobic conditions.
\end{abstract}

Keywords: biodegradation, DDT, molasses, potassium nitrate, anaerobic conditions.

Received 14 November 2016; Accepted 26 September 2017; Published online 10 October 2017

\section{Introduction}

DDT (1,1,1-trichloro-2,2-bis(4-chlorophenyl) ethane) has been widely used since the 1940s as an insecticide to control mosquito-borne malaria and typhus (Foght et al. 2001). Its use was banned in most countries by the early 1980s due to its deleterious impact on wildlife and human health via the food chain (Purnomo et al. 2011). Despite having been banned for over 40 years, DDT contamination is still widely prevalent in many sites around the world. In Colombia, it is estimated that there is $5000 \mathrm{~m}^{3}$ of DDT-contaminated soils (Arbeli 2009).

DDT has a high persistence in soil (half-life between 10-50 years) due to its molecular structure, which contains chlorinated aliphatic and aromatic structures that impart great chemical stability. Additionally low aqueous solubility and adsorption of DDT onto soil organic matter decreases its degradation by microorganisms (Robertson and Alexander 1998). The lipophilic properties of DDT allow it to accumulate in the food chain and in the fatty tissues of organisms, affecting the central neural system, liver and kidneys, and causing reproductive disorders. The International Agency for Research on Cancer (IARC) has determined that DDT is possibly carcinogenic to humans (US-DHS 2002).

Considering their potential negative effects, it is very important to develop an efficient remediation technology for DDT contaminated soils. Bioremediation has been the cost-effective method of treating various pesticides (aldrin, heptachlor, endosulphan, including DDT) (Rani and Dhania 2014).

Reductive dechlorination is a fundamental pathway for DDT degradation in the absence of free oxygen because the five electrophilic chlorine atoms on the DDT molecule make aerobic oxidative degradation difficult. Reductive dechlorination is a form of anaerobic respiration in which the chlorinated compound is used as the terminal electron acceptor by dechlorinating microorganisms (Holliger and Schumacher 1994).

It has been demonstrated that bioremediation of DDT is a co-metabolic process requiring an additional organic substrate (electron donor, organic carbon source) to provide energy (electrons) to indigenous microorganisms (Baczyński 2013). In recent years, evidence has shown that organic acids, alcohols, glucose, and complex organic materials acting as electron donor substances can be used in contaminated sites for the reductive dechlorination of chlorinated pollutants (Chen et al. 2013; Ortiz et al. 2013)

The rationale behind the use of soluble or biodegradable co-substrates in the degradation of persistent molecules is that these co-substrates can promote microbial growth and induce the activation of enzymes that participate in pollutant degradation (Purnomo et al. 2010). 


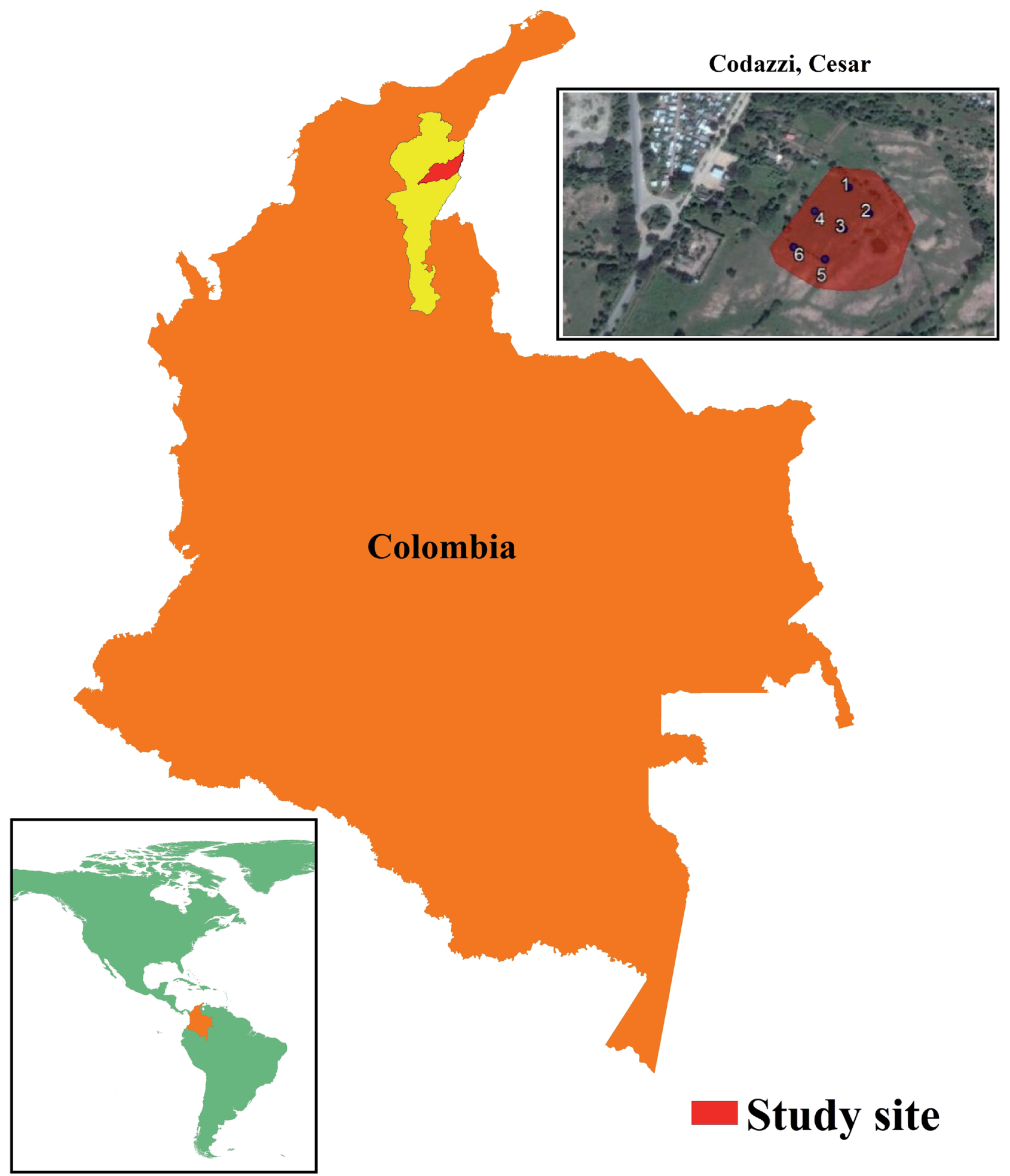

Fig. 1 Study site.

Further, addition of easily biodegradable organic matter stimulates anaerobic, low-redox potential conditions necessary for intensive metabolism of DDT (You et al. 1996).

Studies on the degradation of DDT using liquid-phase tests inoculated with sediment containing DDT-degrading microflora, found that DDT removal was fastest when yeast extract was used as a substrate, while glucose was the slowest.
This research evaluates anaerobic biodegradation of DDT in laboratory and pilot scale experiments using a co-substrate and an electron acceptor to stimulate soil microbial populations. Based on the degradation rate, molasses was selected as a possible supplemental carbon source, along with nitrate (in the form $\mathrm{KNO}_{3}$ ) as the nitrogen source. In the first phase, lab-scale tests were established in microcosms to investigate the individual and interactive effects of the co-substrate (molasses) and 
electron acceptor (potassium nitrate) on biodegradation of DDT. The second-phase developed and evaluated the biodegradation kinetics of DDT in the absence of oxygen at a larger scale by applying an optimal strategy in a fixed bed reactor. The effect of relevant variables, such as concentrations of DDT and physicochemical characteristics, was investigated for both experimental phases.

\section{Materials and methods}

\subsection{Soil collection}

Soil used for both experimental phases was collected at an agricultural area located in Codazzi (Cesar, Colombia) with a previous history of DDT contamination (Fig. 1). This region has soil types ranging from incipient development soils, such as Inceptisols, to soils with a high degree of weathering, such as Oxisols (Instituto Geográfico Agustín Codazzi 1986). Soils were dry and well drained, indicating that these soils may likely have high rates of mineralization of organic matter. The predominant soil textures are sandy loam and loam.

Samples were taken at three different points and top layer $(0-40 \mathrm{~cm})$ of the soils was removed. To ensure homogeneity of pollutants in samples, the soil was crushed and then passed through a $2-\mathrm{mm}$ sieve.

Soil properties were measured using standard methods for soil analysis. Soil texture was characterized using the Bouyoucos method (Bouyoucos 1962). Soil water content was determined by placing samples in an oven at $105^{\circ} \mathrm{C}$ for $24 \mathrm{~h}$ (Jackson 1964). Organic matter (Walkley and Black 1934), pH, electrical conductivity (Jackson 1964), ammonia, nitrate (Nessler 1999) and phosphorus content (Bray and Kurtz 1945) were assessed previously.

\subsection{Microcosm setups}

Lab-scale microcosms were carried out in a $3.8-\mathrm{L}$ rectangular plastic tray. Five treatments were conducted in this phase: (T1) control, (T2) natural attenuation, (T3) molasses, (T4) molasses- $\mathrm{KNO}_{3}$ and (T5) $\mathrm{KNO}_{3}$. Each microcosm was filled with $1 \mathrm{~kg}$ of contaminated soil; three replicates were used. To maintain anaerobic conditions, soil samples were maintained at field capacity, which corresponded to $30 \%$ humidity to generate a low oxygen transfer into and through the soil. Microcosms were moved to closed room without direct sunlight; they were also sealed with a plastic liner to prevent air exchange. For abiotic controls (T1), soil was sterilized by autoclaving at $121{ }^{\circ} \mathrm{C}$ for 15 minutes at $1.05 \mathrm{~kg} / \mathrm{cm}^{2}$ pressure and $2 \mathrm{M} \mathrm{HCl}$ was added as a microbial inhibitor.

The amount of nutrients required for the (T3), (T4) and (T5) treatments was calculated using stoichiometric relationships established by the McCarthy method of the DDT concentration of the soil, and the amount of nitrogen and phosphorus required to produce biomass. The C:N:P ratio was 100:5:1 (mass/mass/mass), which is comparable to the values reported previously in bioremediation studies (Atagana et al. 2003). In treatments $\mathrm{T} 4$ and $\mathrm{T} 5,1.5 \mathrm{~g}$ of $\mathrm{KNO}_{3}$ was added as a nitrogen source and electron acceptor. Molasses was applied in the treatments T3 and T4 in single-doses at the start of the experiment (In et al. 2008). These experiments were conducted for 30 days and the concentrations of DDT were measured (USEPA SW-846 2007; USEPA SW-846 1996a; USEPA SW-846 1996b) at the beginning and end of each treatment.

\subsection{Pilot-scale test}

A pilot-scale ex situ bioremediation experiment was performed in a fixed bed reactor. In this experiment, the microcosm was upscaled by 3 -fold. Likewise, the amount of nutrients (C:N:P ratio of 100:5:1) and the field capacity moisture content of the soil was maintained. The reactor was constructed with $5 \mathrm{~mm}$ thick acrylic material. The dimensions were: $77 \mathrm{~cm} \times 50 \mathrm{~cm} \times 27 \mathrm{~cm}$. The amount of contaminated soil added to the reactor was $60 \mathrm{~kg}$.

DDT concentrations were measured every 4 days during a 1-month period and the degradation kinetics were assessed. At the end of the treatment, predominant colonies were isolated and identified during the biostimulation strategy through biochemical and molecular tests.

Tab. 1 Physical and chemical properties of contaminated soil samples from Codazzi (Cesar, Colombia).

\begin{tabular}{|l|c|}
\hline Parameters & Value \\
\hline Soil texture & Loam \\
\hline Sand (\%) & 38 \\
\hline Silt (\%) & 36 \\
\hline Clay (\%) & 26 \\
\hline $\mathrm{pH}$ & 6.6 \\
\hline Organic matter (\%) & 1.9 \\
\hline Water content (\%) & 1.4 \\
\hline Electrical conductivity $\left(\mathrm{dSm}^{-1}\right)$ & 0.12 \\
\hline $\mathrm{N}-\mathrm{NH}_{4}\left(\mathrm{mg} \mathrm{kg}^{-1}\right)$ & 14 \\
\hline $\mathrm{N}-\mathrm{NO}_{3}\left(\mathrm{mg} \mathrm{kg}^{-1}\right)$ & 4 \\
\hline Total phosphorus $\left(\mathrm{mg} \mathrm{kg}^{-1}\right)$ & 120 \\
\hline Total DDT $\left(\mathrm{mg} \mathrm{kg}^{-1}\right)$ & 72.35 \\
\hline
\end{tabular}

\subsection{Analytical methods}

\subsubsection{Chemical and physical parameters}

Redox potential, $\mathrm{pH}$ and electric conductivity values were measured with a portable multimeter HQ40d (Hach, Loveland, CO, USA). Ten grams of soil (dry weight) was mixed with $25 \mathrm{ml}$ of distilled water to a concentration of $1: 2.5$. The mixture was with a vibration stirrers Vortex $\left(\right.$ FALC $^{\circledR}$ ) for 90 seconds and the electrode was inserted 

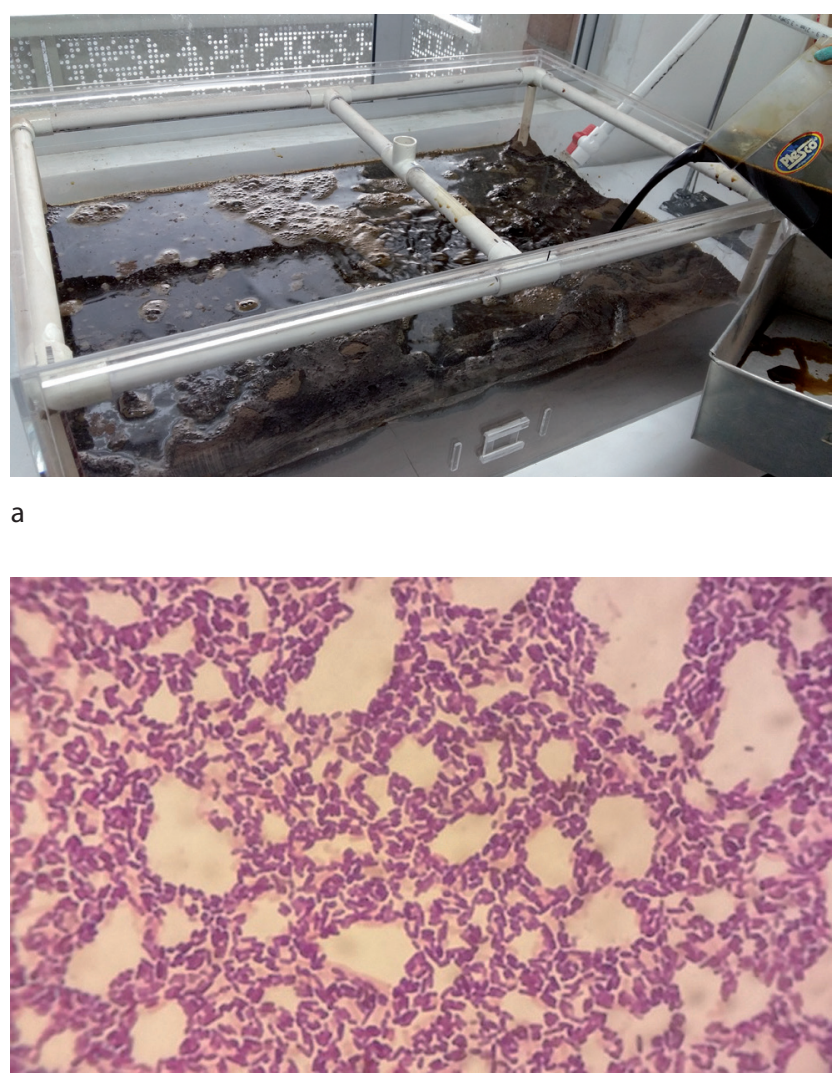

C

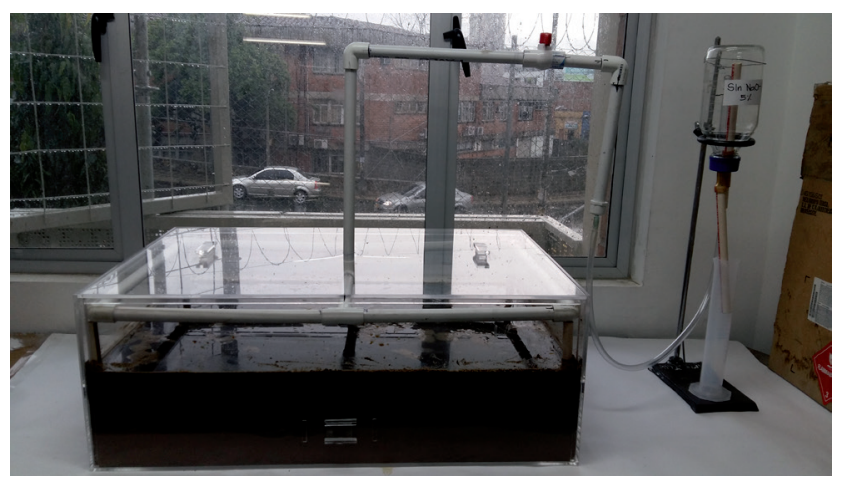

b

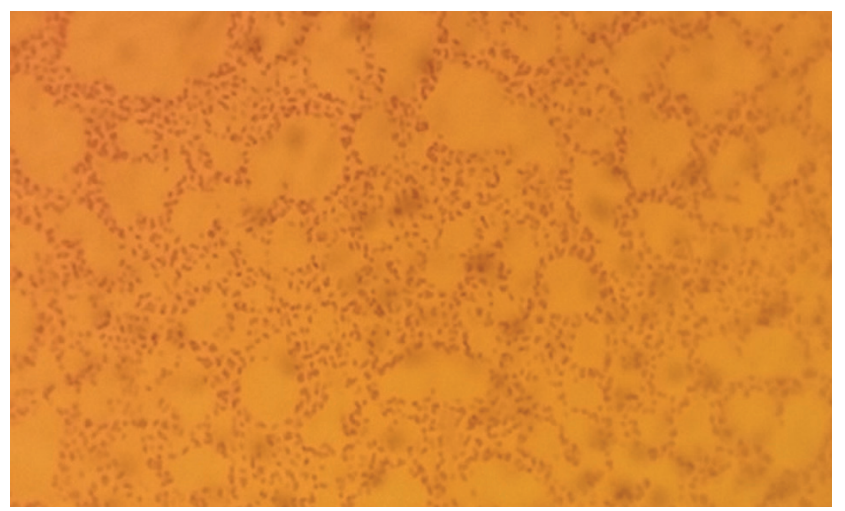

Fig. 2 Lab scale microcosm: a) treatment of molasses- $\mathrm{KNO}_{3}$, b) microcosms experiment, c) bacteria's in contaminated soil (100x), d) bacteria's in decontaminated soil (100x).

in the solution. Soil temperature was measured using a hand-held digital thermometer.

\subsubsection{DDT extraction from soil samples}

Soil samples were extracted by ultrasonic extraction described in US EPA method 3550C with some modifications (USEPA SW-846 2007). Each sample (1 g dry weight) was spiked with $100 \mu \mathrm{L}$ of the surrogate and mixed with anhydrous Na2SO4. A 50:50 (V/V) mixture of hexane and acetone $(10 \mathrm{~mL})$ was added, and the mixture was dispersed for 6 min using an ultrasonic cleaner (Model 2510-DTH; Branson, CT, USA). Finally, the extract was filtered through $3-\mathrm{cm}$ thick glass wool. This procedure was repeated three times. Extracts were decreased to $2 \mathrm{~mL}$ by way of rotary evaporation under vacuum at $55^{\circ} \mathrm{C}$. The percentage of recovery from this method was $101( \pm 2) \%$ for DDT.

Cleanup was performed using US EPA method $3630 \mathrm{C}$ (USEPA SW-846 1996a). Deactivated silica gel (1.5 g) was transferred into a $1 \mathrm{~cm}$ ID column and a 1-cm layer of anhydrous $\mathrm{Na}_{2} \mathrm{SO}_{4}$ was used to cap the silica gel. The column was prewashed with $20 \mathrm{~mL}$ of hexane before use. The concentrated extract was transferred into the column, and then eluted with $8 \mathrm{~mL}$ of hexane (fraction I), $6 \mathrm{~mL}$ of hexane (fraction II), and $1.5 \mathrm{~mL}$ of dichloromethane (fraction III) at a rate of $5 \mathrm{~mL} / \mathrm{min}$.

\subsubsection{GC analyses of DDT}

GC/MS analysis was performed in an Agilent gas chromatograph (Agilent Technologies, CA, USA) equipped with an electron micro-capture detector and a capillary. A $1-\mu \mathrm{L}$ sample was injected and separated on a capillary column (ZB35HT Inferno Zebron 30-m length $\times 0.25-\mathrm{mm}$ ID $\times 0.25-\mu \mathrm{m}$ film thickness, Phenomenex, CA, USA). The GC conditions were: split injection (injector temperature $280^{\circ} \mathrm{C}$, split $1 / 8$ for samples and $1 / 20$ for standard samples); oven temperature programmed from $80^{\circ} \mathrm{C}$ (held for $3 \mathrm{~min}$ ) to $160^{\circ} \mathrm{C}$, then raised by $2.5^{\circ} \mathrm{C} / \mathrm{min}$ to $180^{\circ} \mathrm{C}$ and held for $7 \mathrm{~min}$ (USEPA SW-846 1996b). The carrier gas was Helium. Internal standards were spiked in each sample prior to quantification.

\subsubsection{Heterotrophic plate count}

Bacterial populations were counted by the pour plate method in LB (Luria Bertani) medium. A $1 \mathrm{~g}$ sample was diluted in $9 \mathrm{ml}$ of $0.9 \%$ sterile saline solution (10-1). A $1 \mathrm{ml}$ sample was then taken and transferred to a tube containing $9 \mathrm{ml}$ of sterile saline (10-2). Serial dilutions of soil were prepared until a dilution of 10-4was reached (Carter and Gregorich 2008). Plates were incubated in anaerobic conditions at $35^{\circ} \mathrm{C}$ for 3 days. Soil microbial counts were tested for both phases every four days during 1 month. 


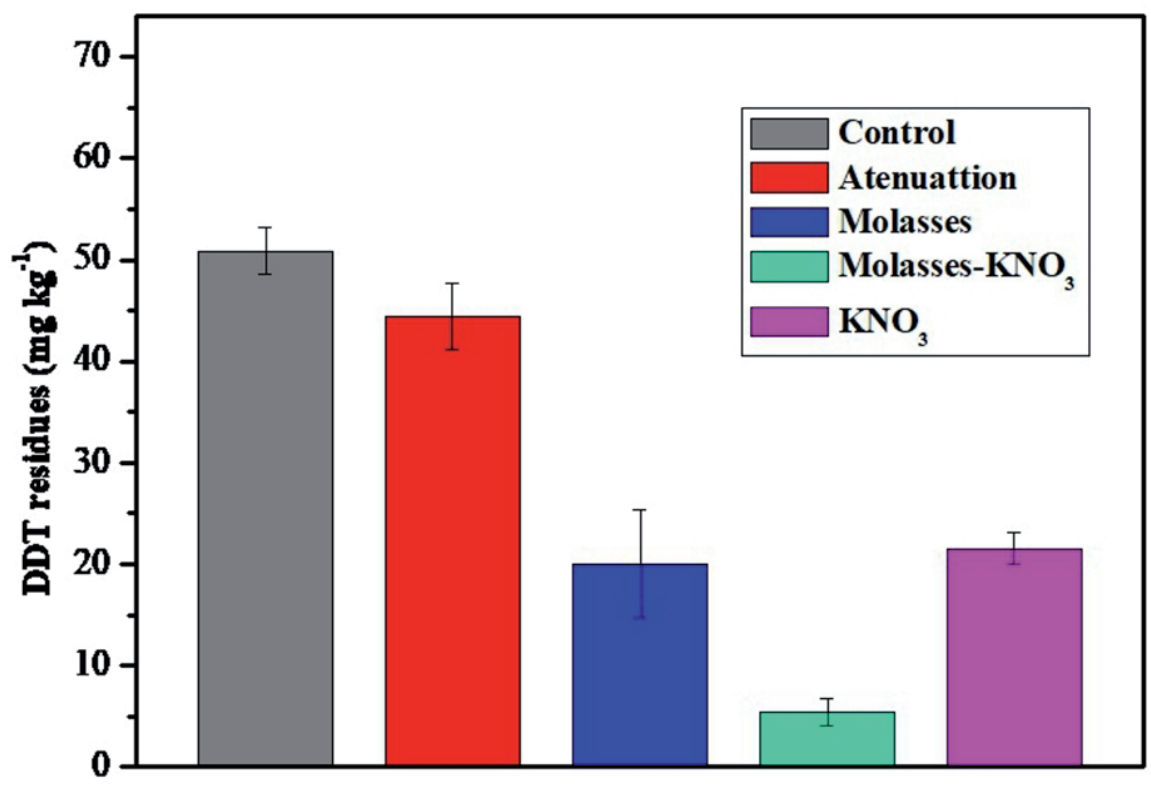

Fig. 3 Final concentration of DDT for each microcosm treatment after 1 month of incubation. Error bars represent standard deviation of results.

\subsection{Microorganism isolation in the reactor}

Soil bacterial strains before and after the treatment applied at the pilot scale were isolated from colonies formed on the plates after incubation at $35{ }^{\circ} \mathrm{C}$ for 3 days (Carter and Gregorich 2008). The isolated colonies formed on the LB agar plates were identified using biochemical tests such as gram stain and catalase. Catalase activity was determined by adding a fragment of a purified colony to hydrogen peroxide and observing the presence (catalase $(+)$ ) or absence of bubbles (catalase $(-)$ ) (Maehly 1954). Gram staining test was determined by Carlone's Method (Carlone 1982) and was observed under a light microscope (Nikon E200, Japan ) with a magnification of $100 \times$.

\subsection{Identification of cultivable bacteria}

The isolates corresponding for B1 (contaminated soil bacteria) and B2 (clean soil bacteria) were purified by repetitive sub-culturing on nutritive agar. Genomic DNA was extracted using the GeneJet Genomic DNA Purification Thermo Scientific kit following the protocol for Gram negative bacteria (Sambrook and Russell 2001).

The 16S rRNA gene was amplified by PCR using 27F (5'-AGAGTTTGATCCTGGCTCAG-3' and 1492R (5'-TACGGYTACCTTGTTACGACTT-3') primers. Each PCR amplification cycle consisted of $30 \mathrm{sec}$ at $94^{\circ} \mathrm{C}$, $30 \mathrm{sec}$ at $55^{\circ} \mathrm{C}$ and $1 \mathrm{~min}$ at $72^{\circ} \mathrm{C}$. PCR amplification was confirmed by agarose gel electrophoresis. The amplified PCR product was purified using the PureLink PCR Purification Kit (Invitrogen Life Technologies, Burlington, Ontario, Canada). The $16 \mathrm{~S}$ rDNA sequencing from the isolates was analyzed by the BLASTN tool with GenBank databases on NCBI (www.ncbi.nlm.nih.gov).

\section{Results and discussion}

\subsection{Soil properties}

After 1 month of incubation, physical and chemical properties of the soil varied. Phosphorus content in the soil increased to $127 \mathrm{mg} \mathrm{kg}^{-1}$; content of nitrogen $\mathrm{N}-\mathrm{NH}_{4}$ and $\mathrm{N}-\mathrm{NO}_{3}$ also increased to values 6 and $23 \mathrm{mg} \mathrm{kg}{ }^{-1}$, respectively, due to the addition of molasses and potassium nitrate solution (nitrogenous compounds). Studies have shown that the addition of $\mathrm{N}$ and $\mathrm{P}$ to soil contaminated with organic compounds stimulates biodegradation and increases the diversity of microbial species (Bray and Kurtz 1945). The soil texture had fixed percentages of sand, silt and clay: 40,36 and $24 \%$ respectively. Previous research showed that the degradation of DDT is more favorable at a $\mathrm{pH}$ of approximately 7 rather than at basic pH values close to 9 (Rittmann and McCarty 2001). At the end of treatment $\mathrm{T} 4$, the $\mathrm{pH}$ increased to 7.3; due to flooding conditions $\mathrm{pH}$ tends to increase as a result of consumption of hydrogen cations $(\mathrm{H}+)$ in the reduction reactions.

\subsection{Microcosm experiments}

Changes in the concentration of DDT for each treatment are presented in Fig. 3. The control exhibited a decrease in DDT concentration of $30.3 \%$, and attenuation natural treatment (control) resulted in a decrease of $32.85 \%$ after four weeks. Loss of DDT in the control 


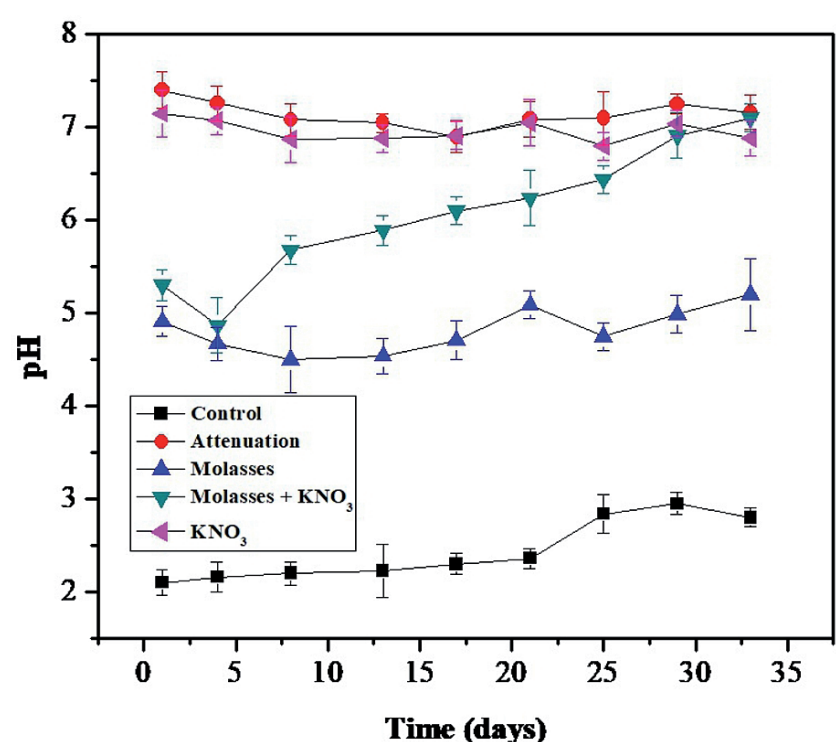

Fig. $4 \mathrm{pH}$-dependent variation for each treatment. Error bars represent standard deviation of results.

treatment may be attributed to abiotic factors such as chemical transformations by adding $\mathrm{HCl}$ solution. Likewise, there is a possibility that some communities of microorganisms may tolerate extreme environments, as in this case where the soil presented low pH (Quatrini and Johnson 2016).

The nutrient additions affected the removal rate of pesticides when compared with the control and attenuation treatment. The results indicated that the application of either molasses or $\mathrm{KNO}_{3}$ could accelerate DDT dechlorination significantly.

The DDT concentration was reduced by $92.5 \%$ with the application of molasses to the soil $+\mathrm{KNO}_{3}$; by $72.3 \%$ with the molasses treatment, and by $70.2 \%$ with the $\mathrm{KNO}_{3}$ treatment. The addition of molasses $+\mathrm{KNO}_{3}$ showed the greatest effect in accelerating DDT dechlorination. This was primarily because the combination electron donor/acceptor produces a synergistic effect; molasses has a complex composition (sugars, proteins, minerals, among others) with a high microbial load and, combined with a terminal electron acceptor with a high reductive potential $\left(\mathrm{NO}^{3-}\right)$, it causes acceleration of contaminant metabolism and high rates of degradation, as obtained in treatment (T4). Several studies suggested that the application of molasses as an organic carbon substrate to create an anaerobic reducing environment through the use of microbes to facilitate dechlorination of contaminants. In general terms, molasses provides more organic carbon to microbes in the soil so that they increase in number and metabolize the contaminants (Brent 2012). Results confirmed the importance of addition an easy biodegradable co-substrate for the effective anaerobic biodegradation of DDT. This was particularly clear for samples with no electron donor added, where the decomposition of DDT was low (T5). The application of both an electron donor substance and an electron acceptor might be a feasible strategy to accelerate the reductive dechlorination of DDT. Therefore, results verify previous studies where it was found that reductive dechlorination of DDT under anaerobic conditions is much faster than the dehydrochlorination under aerobic conditions (Atlas and Bartha 1993).

\subsection{Statistical analysis}

An analysis of variance (ANOVA) was performed to compare whether applied bioremediation treatments differ significantly in DDT degradation $(\mathrm{p}<0.05)$. The high value of $F$ (62.06) indicates that individual and combined application of nutrients affect the rate of removal of DDT in different bioremediation protocols, showing that there is significant difference between the means of the five treatments. The homogeneity of variances was demonstrated using Brown and Forsythe test. The p-value (0.25) was > 0.05 , indicating equal variances in the treatments applied.

\subsection{Eh and $\mathrm{pH}$ values of the reaction systems}

The $\mathrm{pH}$ variations are showed in figure 4 for each microcosm. The $\mathrm{pH}$ is an important physical factor that influences the biodegradation of organochlorine compounds, as it may affect the microbial activity and bioavailability of carbon and energy sources (Dibble 1979). In the control treatment, $\mathrm{pH}$ varied in the range between 2-2.5 due to the addition of $\mathrm{HCl}$ solution as a microbial inhibitor. This condition is toxic to microorganisms and affects the degradation of organochlorine compounds (Matzner and Prenzel 1992).

For treatment T3, soil pH decreased to values close to 5 caused by the application of a molasses solution with $\mathrm{pH}$ in the range 5.5-6. Treatment $\mathrm{T} 2$ maintained the $\mathrm{pH}$ value of 7.1 and its behavior was similar throughout the study because it nutrients were not added. The treatment with the addition of $\mathrm{KNO}_{3}$ showed a $\mathrm{pH}$ variation ranging between 7-7.5 because potassium nitrate in solution results in essentially a neutral effect on the soil. The $\mathrm{pH}$ behavior for treatment T4 increased from 5.5 to 7.2, possibly due to adding nutrients to the soil. The results showed that the $\mathrm{pH}$ favored a higher rate of degradation of DDT. The greatest loss of DDT was in treatment T4 where in the second week, $\mathrm{pH}$ was in the range of 6.57 , compared to the $\mathrm{pH}$ in the molasses assays (T3) was above 5-5.5 during the bioremediation.

Values of Eh for treatments at each sampling time are presented in Table 2. From the beginning to the 21th of incubation, Eh values of the reaction systems were significantly different for treatments T1, T2 and T5 with positive values recorded until the third week. The more rapid decrease in redox potential occurred in treatment T4 due to the greater amount of bioavailable carbon, which likely resulted in greater microbial oxygen consumption that drove the potential redox down. These results showed that the application of molasses or $\mathrm{KNO}_{3}$ could enhance the reducibility of the reaction system, and the effect of 
Tab. 2 Time course of redox potential values for each treatment.

\begin{tabular}{|c|c|c|c|c|c|c|c|c|c|}
\hline \multirow{3}{*}{ Treatments } & \multicolumn{9}{|c|}{ Redox potential (mV) } \\
\hline & \multicolumn{9}{|c|}{ Time (days) } \\
\hline & 1 & 4 & 8 & 13 & 17 & 21 & 25 & 29 & 33 \\
\hline \multirow{2}{*}{$\begin{array}{l}\text { 1. Control } \\
\text { 2. Natural attenuation }\end{array}$} & 150.7 & 140.6 & 120 & 82.3 & 70.6 & 30.5 & 20.3 & 8.34 & -1.5 \\
\hline & 122 & 95.9 & 80.3 & 50.7 & 45.3 & 20 & -1.5 & -5.1 & -18.3 \\
\hline 3. Molasses & -10.1 & -13.6 & -63.1 & -125.8 & -140 & -160.2 & -176 & -180 & -185 \\
\hline 4. Molasses $+\mathrm{KNO}_{3}$ & -89.4 & -90.2 & -105 & -113.9 & -119 & -124 & -163 & -231 & -265 \\
\hline 5. $\mathrm{KNO}_{3}$ & 73.5 & 65.8 & 56.5 & 34.3 & 1.5 & -35.5 & -50.3 & -72.2 & -80.8 \\
\hline
\end{tabular}

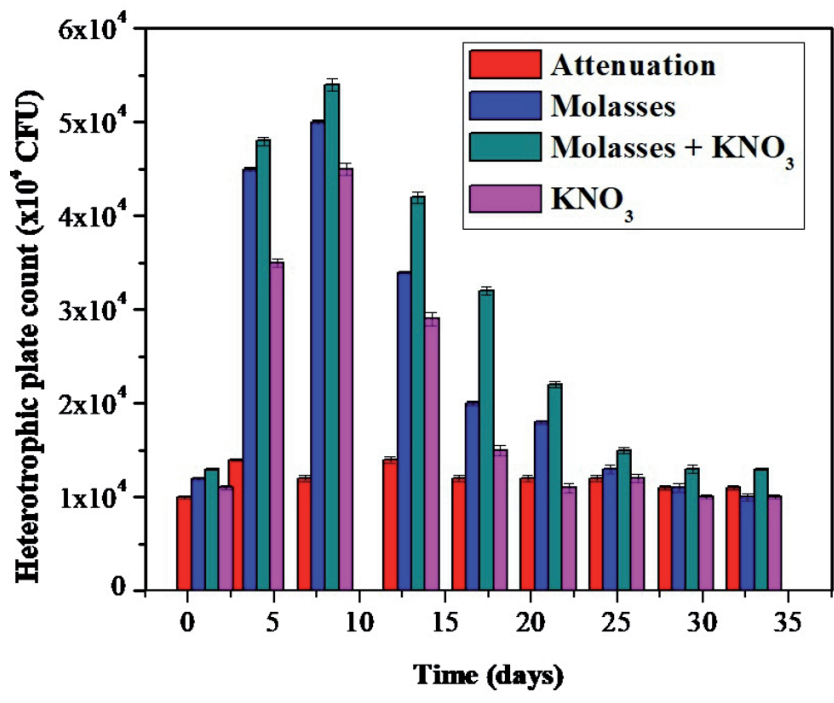

Fig. 5 Heterotrophic plate count in the microcosm treatment for each sampling time. Error bars represent standard deviation of results.

molasses was greater than that of $\mathrm{KNO}_{3}$. Furthermore, the application of molasses $+\mathrm{KNO}_{3}$ had the greatest effect in enhancing the reducibility of the reaction system, indicated a synergistic reaction between molasses and $\mathrm{KNO}_{3}$.

\subsection{Heterotrophic plate count in microcosm}

Bacterial growth during the biodegradation assays are presented in figure 5. The heterotrophic count in the lab-scale experiment showed an increase of CFU (colony forming units) in the first week of incubation and, for the treatments T3, T4 and T5, lasted until the second week. During the third week, heterotrophic bacteria decreased considerably and possibly caused by the lack of nutrients in the soil. In the attenuation treatment, CFUs showed a stable behavior during treatment because no carbon and energy source was added. Treatment T4 had a greater density of bacteria compared with the treatments $\mathrm{T} 3$ and $\mathrm{T} 5$, with a maximum value of $5.4 \times 104 \mathrm{CFU} / \mathrm{g}$ soil.

Mal'tseva and Golovleva (1985) mentioned that the activity of the dehydrogenase during the intake of carbon amendments with high content of energy can generate cofactors that can be involved in the dechlorination of

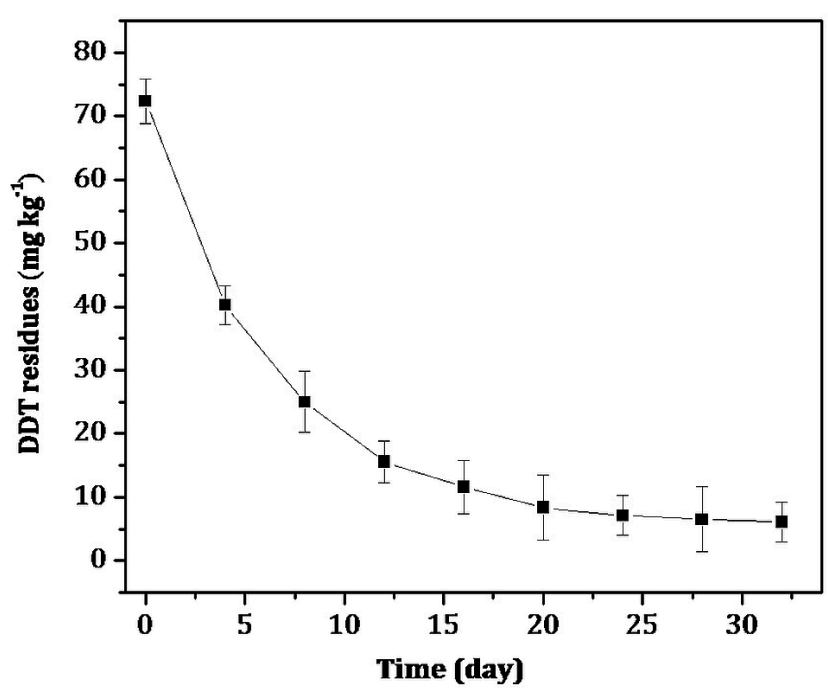

Fig. 6 Evolution of DDT concentration in the reactor during treatment (T4). Error bars represent standard deviation of results.

the DNA. The results show that DDT degradation was directly proportional to growth of the cultures and the indigenous microbial population in the soil was able to utilize molasses $+\mathrm{KNO}_{3}$ as a carbon and energy source, due to the lower concentration of DDT in treatment T4, which had greater CFUs.

\subsection{Pilot-scale test}

Concepts related to the greatest loss of DDT observed in the microcosm studies were extended to a larger scale. The molasses- $\mathrm{KNO}_{3}$ treatment was selected and performed in a fixed bed reactor. Changes of residues of DDT in the reactor are presented in figure 6 . The results showed DDT concentration was reduced by $91.54 \%$ and declined rapidly in the first 9 days and then slowly after 24 days.

In this study, the degradation of DDT in soil fit a pseudo-first order kinetic relation, which agreed with many prior investigations. Previous research found that the anaerobic dechlorination of DDT in the sediment by adding short chain organic carbon sources was pseudofirst-order kinetics (Zhao et al. 2002).

The kinetics equation was $\ln C_{t}=-k t+\ln C_{0}$, where $t$ is the degradation time, $\mathrm{C}_{0}$ is the initial concentration of 
DDT, $C_{t}$ is the residue of DDT at the $t$ day, $k$ is the degradation rate constant, and the half-life of DDT is $0.693 / \mathrm{k}$. The value obtained was a constant degradation rate, indicating that DDT declines to 0.0784 per day parts of pollutant with a half-life of 8.9 days. This shows that the application molasses- $\mathrm{KNO}_{3}$ under anaerobic conditions, can significantly reduce the DDT half-life.

It has been shown that the combination of a co-substrate/electron acceptor applied to DDT-contaminated soil can accelerate the dechlorination of organochlorine in anaerobic conditions and achieve half-lives between 8 and 12 days (Liu et al. 2015).

\subsection{Isolation and identification of culturable bacteria}

Two representative colonies were isolated, one belonging to DDT contaminated soil and a second colony after being applied biostimulation treatment in the reactor. The catalase test is one of the most useful diagnostic tests for the recognition of bacteria due to its simplicity. In performing the catalase test, bacteria $\mathrm{B} 1$ bubble was observed and in contrast, bacteria $\mathrm{B} 2$ produced no bubble, indicating that the isolated bacterium is catalase negative and could not mediate the decomposition of $\mathrm{H}_{2} \mathrm{O}_{2}$ to produce $\mathrm{O}_{2}$. For test Gram stain was obtained bacilli Gram positive in both bacteria. Previous research demonstrated that Gram-negative and Gram-positive bacteria, such as Alcaligeneseutrophus, Hydrogenomonas sp. and Pseudomonas putida, which have the metabolic capability to attack DDT (Sonkong et al. 2008).

It was possible to extract the DNA and successfully amplify the gene $16 \mathrm{~S}$ of the samples under study. According to the Blastn tool, sequences homologous to samples B1 (contaminated soil bacteria) and B2 (soil bacteria after treatment) were detected with the genus Bacillus, which were used as references for subsequent phylogenetic analysis for samples, as shown in Table 3.

Tab. 3 Identification of bacterial isolates before and after the treatment.

\begin{tabular}{|l|c|l|}
\hline Isolate & Degree of similarity & Description \\
\hline Bacillus circulans & $99 \%$ & Before treatment \\
\hline Bacillus megaterium & $100 \%$ & ${\text { After treatment } \mathrm{T}_{4}}$ \\
\hline
\end{tabular}

According to the distance matrix, that could be identified for bacteria B1, Bacillus circulans and for bacteria $\mathrm{B} 2$, to the reference sequence of Bacillus megaterium, indicating Bacillus gender was able to resist to the contaminant present in the soil. Researchers have demonstrated the capabilities of anaerobic bacteria to degrade DDT through reductive dechlorination mechanisms, such as: Bacillus sp. Pseudomonas aeruginosa, Escherichia coli. Proteus vulgaris (Katayama 1993).

\section{Conclusions}

The biostimulation treatment with molasses- $\mathrm{KNO}_{3}$ represented the highest percentage of DDT removal (92.5\%). By contrast, removal of $72.3 \%$ and $70.2 \%$ was obtained in the molasses (T3) and $\mathrm{KNO}_{3}$ treatments (T5), respectively. This shows that the combination of a donor electron substance and acceptor electron produces a great increase in the presence of heterotrophic bacteria in the soil, and consequently an increase the DDT dechlorination. Although the contaminant is used as the sole source of carbon and energy in most cases, the microorganisms present in the soil are unable to metabolize a compound as sole carbon source. Therefore, a kinetic study evaluated in the fixed bed reactor demonstrated the efficiency of treatments in anaerobic conditions to bioremediate DDT contaminated soil. It was concluded, based on the constant degradation rate that 0.0784 parts of pollutant disappears per day, that it is possible to carry out bioremediation of DDT through biostimulation at a larger scale.

Bacterial plate count increased, corresponding to DDT removal. As bacterial count increased, the DDT concentration was reduced. A $16 \mathrm{~S}$ rDNA analysis allowed us to identify predominant bacteria, such as Bacillus circulans before treatment and Bacillus megateriun during bioremediation T4, which indicates the great capacity of the Bacillus gender to resist contaminant in the soil.

\section{Acknowledgements}

The authors would like to thank the National University of Colombia, Medellin, especially the Faculty of Mines, for the support through the infrastructure of Bioremediation and Technological Development laboratory. The authors would also like to thank the Information System Research Hermes Medellin for the financing of this investigation (No. 200000013887) and to the administrative department of Science, Technology and Innovation-COLCIENCIAS for the scholarship Young Researchers (No. 645). We also like to give special thanks to Prof. Roy Sidle for greatly improved the quality of this paper.

\section{REFERENCES}

ARBELI, Z. (2009): Biodegradation of persistent organic pollutants (POPs): the case of polychlorinated biphenyls (PCB). Acta Biológica Colombiana 14(1), 55-86.

ATAGANA, H. I., HAYNES, V., WALLIS, F. M. (2003): Optimization of soil physical and chemical conditions for the bioremediation of creosote-contaminated soil. Biodegradation 14(4), 297-307. https://doi.org/10.1023/A:1024730722751 
ATLAS, R. M., BARTHA, R. (1993): Microbial ecology : fundamentals and applications. 3rd ed. Redwood City, Calif.: Benjamin/ Cummings Pub. Co.

BACZYŃSKI, T. (2013): Influence of process parameters on anaerobic biodegradation of DDT in contaminated soil. Preliminary lab-scale study. Part II. Substrates and pH control. Environment Protection Engineering 39(1), 5-16. https://doi.org/10.5277 /EPE130101

BOUYOUCOS, G. J. (1962): Hydrometer method improved for making particle size analysis of soils. Agronomy Journal 54(5), 464-465. https://doi.org/10.2134/agronj1962.000219 $62005400050028 \mathrm{x}$

BRAY, R., KURTZ, L. T. (1945): Determination of total, organic and available forms of phosphorus in soil. Soil Science 59(1), 39-46. https://doi.org/10.1097/00010694-194501000-00006

BRENT, A. (2012): A Study of Enhanced De-chlorination and Bio-Remediation: Molasses Injections into Groundwater, Natural Resource Management and Environmental Science Department, California Polytechnic State University.

CARLONE, G. M., VALADEZ, M. J., PICKETT, M. J. (1982): Methods for distinguishing gram-positive from gram-negative bacteria. Journal of Clinical Microbiology 16(6), 1157-1159.

CARTER, M. R., GREGORICH, E. G. (2008): Soil sampling and methods of analysis. Canadian Society of Soil Science, CRC Press, Taylor and Francis Group, USA.

CHEN, M., CAO, F., LI, F., LIU, C., TONG, H., WU, W., HU, M. (2013): Anaerobic Transformation of DDT Related to Iron(III) Reduction and Microbial Community Structure in Paddy Soils. Journal of Agricultural and Food Chemistry 61(9), 2224-2233. https://doi.org/10.1021/jf305029p

DIBBLE, J. T., BARTHA, R. (1979): Effect of environmental parameters on the biodegradation of oil sludge. Applied and Environmental Microbiology 37(4), 729-739.

FOGHT, J., APRIL, T., BIGGAR, K., AISLABIE, J. (2001): Bioremediation of DDT-Contaminated Soils: A Review. Bioremediation Journal 5(3), 225-246. https://doi.org/10.1080/20018891079302

HOLLIGER, C., SCHUMACHER, W. (1994): Reductive dehalogenation as a respiratory process. Antonie van Leeuwenhoek 66(1-3), 239-246. https://doi.org/10.1007/BF00871642

IN, B.-H., PARK, J.-S., NAMKOONG, W., HWANG, E.-Y., KIM, J.-D. (2008): Effect of co-substrate on anaerobic slurry phase bioremediation of TNT-contaminated soil. Korean Journal of Chemical Engineering 25(1), 102-107. https://doi.org/10.1007 /s11814-008-0018-1

INSTITUTO GEOGRÁFICO AGUSTÍN CODAZZI (1986): Estudio semidetallado de suelos de los municipios del sur del departamento del Cesar.

JACKSON, K. L. (1964): Análisis Químico del Suelo, Omega. Barcelona-España.

KATAYAMA, A., FUJIMORA, Y., KUWATSUKA, S. (1993): Microbial Degradation of DDT at Extremely Low Concentrations. Journal of Pesticide Science 18(4), 353-359. https://doi .org/10.1584/jpestics.18.4_353

LIU, C., XU, X., FAN, J. (2015): Accelerated anaerobic dechlorination of DDT in slurry with Hydragric Acrisols using citric acid and anthraquinone-2,6-disulfonate (AQDS). Journal of Environmental Sciences 38, 87-94. https://doi.org/10.1016/j .jes.2015.05.005

MAEHLY, A. C. (1954): The Assay of Catalases and Peroxidases. Methods of Biochemical Analysis, 1. John Wiley \& Sons, Inc., Hoboken, NJ, USA. https://doi.org/10.1002/9780470110171.ch14
MAL'TSEVA, O. V., GOLOVLEVA, L. A. (1985): Role of additional substrates in DDT degradation by cultures of Pseudomonas aeruginosa. Mikrobiologiia 54(2), 222-226.

MATZNER, E., PRENZEL, J. (1992): Acid deposition in the German solling area: Effects on soil solution chemistry and $\mathrm{Al}$ mobilization. Water, Air, Soil Pollution 61(3-4), 221-234. https://doi.org/10.1007/BF00482606

ORTÍZ, I., VELASCO, A., LE BORGNE, S., REVAH, S. (2013): Biodegradation of DDT by stimulation of indigenous microbial populations in soil with cosubstrates. Biodegradation 24, 215-225. https://doi.org/10.1007/s10532-012-9578-1

PURNOMO, A. S., KOYAMA, F., MORI, V., KONDO, R. (2010): DDT degradation potential of cattle manure compost. Chemosphere 80(6), 619-624. https://doi.org/10.1016/j .chemosphere.2010.04.059

PURNOMO, A. S., MORI, T., KAMEI, I., KONDO, R. (2011): Basic studies and applications on bioremediation of DDT: A review. International Biodeterioration \& Biodegradation 65(7), 921-930. https://doi.org/10.1016/j.ibiod.2011.07.011

QUATRINI R., JOHNSON, D. B. (2016): Acidophiles: Life in Extremely Acidic Environments. Caister Academic Press. https://doi.org/10.21775/9781910190333

RANI, K., DHANIA, G. (2014): Review Article Bioremediation and Biodegradation of Pesticide from Contaminated Soil and Water - A Noval Approach. International Journal of Current Microbiology and Applied Sciences 3(10), 23-33.

ROBERTSON, B. K., ALEXANDER, M. (1998): Sequestration of DDT and dieldrin in soil: Disappearance of acute toxicity but not the compounds. Environmental Toxicology Chemistry 17(6), 1034-1038. https://doi.org/10.1002/etc.5620170608

SAMBROOK, J., RUSSELL, D. W. (2001): Molecular cloning: a laboratory manual. Third ed. Cold Spring Harbor Laboratory Press.

SONKONG, K., PRASERTSAN, P., SOBHON, V. (2008): Screening and identification of $\mathrm{p}, \mathrm{p}^{\prime}$-DDT degrading soil isolates. Songklanakarin Journal of Science Technology 30(Suppl. 1), 103-110.

US-DHS (2002): Toxicological Profile for DDT, DDD and DDE. Atlanta.

USEPA SW-846 (1996a): Test Methods for Evaluating Solid Waste Method 3630C.

USEPA SW-846 (1996b): Determinative chromatographic separations Method 8000B.

USEPA SW-846 (2007): Test Methods for Evaluating Solid Waste Method 3550C.

WALKLEY, A., BLACK, I. A. (1934): An examination of the Degtjareff method for determining soil organic matter and a proposed modification of the chromic acid titration method. Soil Science 27, 29-37. https://doi.org/10.1097/00010694-193401000 $-00003$

YOU, G., SAYLES, G. D., KUPFERLE, M. J., KIM, I. S., BISHOP, P. L. (1996): Anaerobic DDT biotransformation: Enhancement by application of surfactants and low oxidation reduction potential. Chemosphere 32(11), 2269-2284. https://doi .org/10.1016/0045-6535(96)00121-X

ZHAO, H., QUAN, X., YANG, F., CHEN, J., ZHAO, Y. (2002): Basic research on the bioremediation of $\mathrm{p}, \mathrm{p}^{\prime}$-DDT contaminated sediment by adding short chain organic substrate. Acta Sci 22(1), 51-55. 